\title{
Recycling of Cullet, Waste Clay Bricks and Wastes Resulted from Wheat and Sugarcane Cultivations in the Manufacture of Fired Clay Bricks
}

\author{
M. H. ROUSHDY \\ Chemical Engineering Department, Faculty of Engineering \\ The British University in Egypt (BUE) \\ El-Sherouk 11837, Cairo, EGYPT
}

\begin{abstract}
The agriculture wastes are considered as a big environmental problem. The main purpose of this research is to determine the possibility of producing fired clay bricks from a mixture of agriculture wastes in addition to other wastes. The first type of wastes is the cullet while the second type is the wastes is the waste clay bricks (Homra) and the third is an agricultural residue obtained from wheat and sugarcane cultivation.

The first step of the experimental work is performing XRF and sieve analysis for raw materials. Brick samples with Cubic shape with dimensions $50 \times 50 \times 50 \mathrm{~mm}^{3}$ were formed by $1 \mathrm{MPa}$ dry pressing then drying at $120{ }^{\circ} \mathrm{C}$ overnight. Tile samples were fired at temperatures of $850 \mathrm{C}$ for $15 \mathrm{~min}$ soaking time. Water absorption,

apparent porosity, and mechanical properties were determined and compared to ES 4763 / 2006 and ASTM C 62 / 2013 standards. According to the previous experimental work, it was found that the samples that has a composition (38\% Desert clay, 20\% Homra, 10\% cullet, 15\% Wheat ash straw, 17\% sugarcane) has the optimum properties with respect to ES 4763 / 2006 and ASTM C 62 / 2013 standards.
\end{abstract}

Key-Words: - Ceramic wastes, Clay Bricks, Cullet, Sugarcane, Wheat, Optimization

Received: October 15, 2020. Revised: March 1, 2021. Accepted: March 5, 2021. Published: March 16, 2021

\section{Introduction}

Bricks are one of the most common and used building materials in construction industry, they are known to be versatile in their use and application. They can be defined as single units that connect with each other by a mortar to form a structure or construction. Bricks are usually made of clay, and recently, concrete. Bricks can be manufactured into specific shapes and sizes depending on the desired product specs. [1]

An important advantage of clay bricks is their ability to mold and extrude easily with the presence of water during manufacturing process, this allows it to be molded easily into the shape and form desired. However, molding clay bricks have started to diminish overtime as extrusion has shown to be a better and more efficient substitute in manufacturing clay bricks. Clay bricks are made by firing up clay in kilns with temperatures in the range of $1000^{\circ} \mathrm{C}$ to $1500^{\circ} \mathrm{C}$ depending on the type of clay used. [1]

Many Researchers investigated the probability of wastes recycling as raw materials for fired clay bricks production, due to the demand of bricks as building materials because of the flexibility of the brick composition. The most utilized wastes from the literature reviews related to waste materials recycling are the different types of sludge and fly ash, pulp residues, sawdust, polystyrene, paper, tobacco, processed waste tea, grass, spent grains, glass windshields, phosphogypsum, cigarette butts and boron concentrator. The utilization of these wastes decreases the bad effects of environmental pollution due to their disposal [1-9].

Abdullatif et al. investigated the effect of adding cigarette filters in the production of fired clay bricks with percentages $5 \%$ and $10 \%$ by volume. The results showed that only one bricks sample with $5 \%$ by volume Cigarette complied with the Egyptian standards for bricks that can be used in non-load bearing uses [10].

Kumar et al. investigated the production of building bricks using black cotton soil, granite waste and fly ash and he found that they are good raw materials for building bricks [11]. Limami et al. investigated the addition of wastewater treatment sludge to the building bricks raw materials. He produced unfired brick samples, of low-energy demand, with wastewater treatment plant sludge additives [12]. Aneke et al., investigate the utilization of scrap plastic wastes and foundry sand in the production of green efficient bricks for masonry structures. He found that these wastes are 
promising raw materials for building bricks production [13].

The main substrates of human diet are sugar. China, Brazil, Australia, Thailand and India are the top five countries in the world in sugar producing [14]. At the year 710 AD Egypt started sugar production [15]. Sugar cane was a source of sugar in sugar production since 1981. Some areas of Upper Egypt are famous with cane plantations as the amount of cultivated cane was 16 million tons in $2009(16 ; 17)$.

On the other hand, Egypt are famous with wheat cultivation as it occupies about $32.6 \%$ of the total winter land area. Wheat straw ash is considered as the most important agricultural residues. Straw consists mainly of lignin, hemicelluloses, and cellulose [18].

Hassan et al. investigate the use of sugarcane bagasse and wheat straw in the fireclay bricks production. Results proved that adding 5\% bagasse with $0.5 \%$ polystyrene beads results and firing for 2 hours at $1250^{\circ} \mathrm{C}$ produced bricks abiding by ASTM standards for C-32 type insulating fireclay bricks. On the other hand, the addition of 5\% wheat straw, despite fulfilling the density and thermal conductivity requirements, resulted in marginal values for cold crushing strength [19].

Many research investigated the possibility of partially replacement of cement with sugarcane to produce an ecofriendly building cement brick in the construction industry with appropriate structure properties. Dawoud et al. study and analyze different techniques used by many researchers to produce in which the cement was replaced by sugarcane bagasse. He also showed the best technique for partially cement replacement with sugarcane without changing the standard properties of the produced cement bricks. [20]

The main objective of the present paper is to investigate the possibility of recycling two types of agriculture wastes which are wheat and sugarcane in addition to broken glass (cullet) and waste building bricks (Homra) as raw materials for fired clay bricks production. The main raw material of building bricks which is the desert clay is replaced by the previously mentioned wastes with different ratios and then an optimization were done using design expert program to get the optimum composition of theses wastes that give the best physical and mechanical properties.

\section{Experimental Work}

\subsection{Raw Materials}

The raw materials were used in this research were as follow:

1) The desert clay that is the main raw material used in fired clay brick production, obtained from Misr Brick Factory (El-Saff, Helwan).

2) The waste building bricks (Homra).

3) Cullet which is waste glass.

4) Agricultural residue obtained from wheat cultivation.

5) Agricultural residue obtained from sugarcane cultivation.

\subsection{Characterization of Raw Materials}

The raw materials characterizations include XRF method for chemical composition determination for all raw materials using Wavelength Dispersive (WD-XRF) Sequential Spectrometer. The distribution of particle size for all the raw materials was determined using BT-2001 Laser Particle Size Analyzer according to ASTM D 422 (2007) [21]

\subsection{Preparation of Mixtures}

1) The wastes glass (cullet) and waste building bricks (Homra) were ground separately to reach particle size less than $1 \mathrm{~mm}$.

2) The agricultural residue obtained from wheat and sugarcane cultivation was sun dried then ground separately to reach particle size less than $1 \mathrm{~mm}$.

3) Part of clay was replaced by both wastes in the bricks making are in range from $0 \%$ till $10 \%$ for cullet sludge and from $0 \%$ till $20 \%$ for agricultural residue obtained from wheat and sugarcane cultivation and waste building bricks (Homra). This way, sixteen mixtures were prepared as raw materials for fired clay bricks preparation.

4) These mixtures were dry mixed then grinded and finally wet mixed $12 \mathrm{~min}$, by adding water with $55 \%$ by weight to produce slurry, using a laboratory ball mill with alumina balls, having a capacity $=500 \mathrm{~g}$.

5) The slurry of mixtures was dried in the laboratory dryer at $250-300{ }^{\circ} \mathrm{C}$ for 5 hours; in order to produce powder contains $5-7 \%$ by weight water.

\subsection{Formation of Brick Samples}

The fired clay bricks formation was carried out as follow:

1) Molding cubic brick samples with dimensions 
$50 \times 50 \times 50 \mathrm{~mm}^{3}$ using under uniaxial dry pressing of 10 bar with the help of $10 \%$ water as a binder.

2) Drying the bricks samples using the dryer. Drying samples at $70{ }^{\circ} \mathrm{C}$ for 4 hours followed by $110^{\circ} \mathrm{C}$ for one hour.

3) Brick specimens were fired using the furnace at $850{ }^{\circ} \mathrm{C}$, for 15 minutes soaking time, and total firing time is 2.25 hours.

\subsection{Fired Clay Bricks Testing}

Characterization or testing the resulted clay bricks as carried out as follow:

1) Determination of the compressive strength for green and fired bricks according to ASTM C 67, (2013) [22]. The compressive strength of each specimen is calculated as follows:

$C=\frac{W}{A}$

Where:

$\mathrm{C}=$ compressive strength of specimen, $\mathrm{N} / \mathrm{mm}^{2}$ (MPa),

$\mathrm{W}=$ maximum load as measured by the testing machine, $\mathrm{N}$.

$\mathrm{A}=$ average cross area between the upper and lower bearing surfaces of the specimen, $\mathrm{mm}^{2}$.

2) Determination of the boiling and cold water absorption and saturation coefficient according to ASTM C 67, (2013) [22]. The test specimens are first dried and cooled then weighed $\left(\mathrm{W}_{\mathrm{d}}\right)$, then submerged in clean distilled water at room temperature for 24 hours then removed and weighed (Ws). The samples were submerged again in hot water where it was heated in boiling water for 5 hours continuously then cooled to room temperature. The specimens were removed and weighed $\left(\mathrm{W}_{\mathrm{b}}\right)$. The cold and boiling water absorption and also saturation coefficient are calculated as follows:

Cold Water Absorption $\%=\frac{W_{s}-W_{d}}{W_{d}} \times 100$

Boiling Water Absorption $\%=\frac{W_{b}-W_{d}}{W_{d}} \times 100$

Saturation Coeff $=\frac{W_{s}-W_{d}}{W_{b}-W_{d}} \times 100$
3) Determination of apparent porosity according to ASTM C 373/1988 (reapproved 2006) [23], and BS EN ISO 10545-3/1997 [24]. After 5 hours boiling, the specimen is hung with light copper wire and dipped in water under a constant height of water from the surface. Both hook and wire weights should be subtracted from the recorded weight of the specimen. This is the weight designated as $(\mathrm{S})$ in the calculation.The apparent porosity $(\mathrm{P})$ is calculated as follows:

$$
P \%=\frac{W_{b}-W_{d}}{W_{b}-S} \times 100
$$

\section{Results and Discussion 3.1 Analysis of Raw Materials 3.1.1 Chemical Analysis of Raw Materials}

The results of XRF analysis of all the raw materials are shown in the following table. Sugarcane bagasse waste is mainly composed of lignin, cellulose, hemicelluloses, fats and silica. Its ultimate composition was established as shown in Table 1. Table 2 shows the chemical analysis of desert clay and Homra. The elevated loss of ignition of waste is due to presence of organic matter. For cullet, silica is the main component so they are promising raw materials for building bricks production. Wheat straw samples are mainly composed of lignin, cellulose, hemicelluloses, proteins and sugars. Its ultimate composition was established as shown in Table 3.

Table 1. Chemical Analysis of Sugarcane Bagasse Waste

\begin{tabular}{|c|c|}
\hline Main & Sugarcane \\
\hline Carbon & 48.7 \\
\hline Hydrogen & 4.9 \\
\hline Nitrogen & 1.3 \\
\hline Phosphorous & 1.1 \\
\hline Silica & 44 \\
\hline
\end{tabular}


Table 2. Chemical Analysis

\begin{tabular}{|c|c|c|c|}
\hline Main constituents & Cullet & Homra & Desert clay \\
\hline $\mathrm{SiO}_{2}$ & 73.58 & 49.94 & 39.97 \\
\hline $\mathrm{Al}_{2} \mathrm{O}_{3}$ & 1.24 & 15.14 & 15.03 \\
\hline $\mathrm{Fe}_{2} \mathrm{O}_{3}$ & 0.23 & 14.43 & 8.26 \\
\hline $\mathrm{TiO}_{2}$ & 0.04 & 1.92 & 0.91 \\
\hline $\mathrm{MnO}$ & 0.007 & ---- & 0.04 \\
\hline $\mathrm{SO}_{3}$ & 0.42 & 1.93 & 6.17 \\
\hline $\mathrm{MgO}$ & 0.17 & 0.66 & 1.59 \\
\hline $\mathrm{CaO}$ & 7.42 & 12.92 & 8.53 \\
\hline $\mathrm{Na}_{2} \mathrm{O}$ & 15.84 & 0.26 & 2.22 \\
\hline $\mathrm{K}_{2} \mathrm{O}$ & 0.05 & 0.74 & 1.11 \\
\hline $\mathrm{Cl}$ & 0.06 & ----- & 1.11 \\
\hline $\mathrm{P}_{2} \mathrm{O}_{5}$ & 0.02 & 0.06 & 0.19 \\
\hline $\mathrm{SrO}$ & ---- & ---- & 0.09 \\
\hline $\mathrm{Cr}_{2} \mathrm{O}_{3}$ & ---- & ---- & 0.02 \\
\hline $\mathrm{ZrO}_{2}$ & ----- & ---- & 0.05 \\
\hline $\mathrm{ZnO}$ & ---- & ---- & 0.02 \\
\hline LOI & ----- & 1.72 & 14.68 \\
\hline
\end{tabular}

Table 3. Chemical Analysis of wheat straw

\begin{tabular}{|c|c|}
\hline Main & Wheat Straw \\
\hline Carbon & 49 \\
\hline Hydrogen & 5.3 \\
\hline Oxygen & 37 \\
\hline Silica & 1.6 \\
\hline Sulfur & 0.66 \\
\hline Potassium & 0.52 \\
\hline
\end{tabular}

\subsubsection{Screen Analysis of Raw Materials}

The results of screen analysis are shown in Fig 1. The mean particle size of desert clay is bigger the size of any type of waste powder.

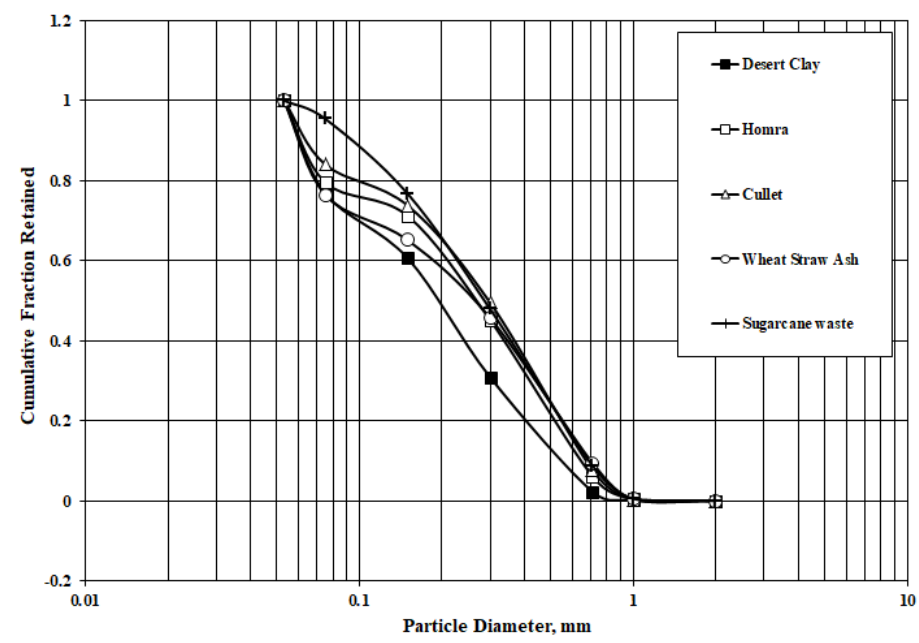

Fig. 1: Cumulative Analysis of Raw Materials

\subsection{Wastes Addition Effect on Green Strength}

Although the dry compressive strength does not appear in any standards as a prerequisite for clay bricks, it was necessary to estimate the effect of waste addition on that strength. The reason for that is the weak nature of green dry clay bricks. A low compressive strength indicates that appreciable losses may occur on handling. On adding waste to clay, the effect of the elevated strength of inorganic constituents clearly appears as the green compressive strength is almost constant ranging 
from 3.8 to $4.8 \mathrm{MPa}$. Past that addition level, pores are thus formed, and the strength drops but the values obtained were comparable to those of plain clay bricks and guaranteed safe handling of dry bricks.

\subsection{Wastes Addition Effect on Percent Open Porosity and Water Absorption 3.3.1 Cold Water Absorption}

The addition of Homra waste (B) increases cold water absorption At $850{ }^{\circ} \mathrm{C}$ firing, enhances absorption of water to cause slaking of the produced calcium oxide according to the reaction: $\mathrm{CaO}+\mathrm{H}_{2} \mathrm{O}$ $=\mathrm{Ca}(\mathrm{OH})_{2}$. Cullet or waste glass $(\mathrm{C})$ addition to the samples fired at $850{ }^{\circ} \mathrm{C}$ there was more liquid phase formation accompanied with dilation in closed pores and expansion due to the entrapment of released gases, mainly $\mathrm{CO}_{2}$, which in turn increase the porosity and hence increase the water absorption. The thermal treatment of waste glass at high temperature released volatile matter which promoted porous structure. Addition of cullet more than $20 \%$ results in samples warping. Addition of wheat straw ash (D) increases the porosity and hence the water absorption. According to the chemical analysis done, the results showed that it contains mainly carbon and oxygen so its addition to the samples increases the amount of gases produced and then increases the porosity and water absorption. Addition of sugarcane bagasse waste ash (E) increases the porosity but with little effect than wheat straw ash and hence the water absorption. According to the chemical analysis done, the results showed that it contains mainly carbon and silica so its addition to the samples increases the amount of gases produced and then increases the porosity and water absorption.

\subsubsection{Boiling Water Absorption}

The effect of waste addition on boiling water absorption is similar to that of cold water. Tables 4 , 5 and 6 show the effect of waste addition on open porosity and water absorption types. The boiling water absorption values are higher than that of cold water absorption values as boiling enhanced the water absorption in the fired building bricks samples.

The equation that shows cold water absorption (CWA) as function of all wastes percentages is the following

$C W A=9.93760+0.04293 H+0.06544 C+$ $0.10859 W+0.07094 S$
The equation that shows hot water absorption (HWA) as function of all wastes percentages is the following

$$
\begin{aligned}
& H W A=15.01319+0.08705 H+ \\
& 0.12207 C+0.20945 W+0.13062 S
\end{aligned}
$$

The equation that shows percent open porosity $(\mathrm{P})$ as function of all wastes percentages is the following

$$
\begin{aligned}
& P=29.71980+0.08807 H+0.15355 C+ \\
& 0.24225 W+0.16953 S
\end{aligned}
$$

From the above equations it was found than the addition of wheat straw ash has the highest effect on

\begin{tabular}{|c|c|c|c|c|c|}
\hline \multicolumn{5}{|c|}{ Percentage } & \multirow{2}{*}{$\begin{array}{c}\text { Porosity, } \\
\text { P (\%) }\end{array}$} \\
\hline Desert Clay & $\mathrm{H}$ & $\mathrm{C}$ & W & $\mathrm{S}$ & \\
\hline 100 & 0 & 0 & 0 & 0 & 30126 \\
\hline 90 & 0 & 10 & 0 & 0 & 322347 \\
\hline 80 & 0 & 0 & 20 & 0 & 3313848 \\
\hline 70 & 0 & 10 & 20 & 0 & 3545817 \\
\hline 80 & 0 & 0 & 0 & 20 & 3283722 \\
\hline 70 & 0 & 10 & 0 & 20 & 3513583 \\
\hline 60 & 0 & 0 & 20 & 20 & 3612094 \\
\hline 50 & 0 & 10 & 20 & 20 & 3864941 \\
\hline 80 & 20 & 0 & 0 & 0 & 31.63218 \\
\hline 70 & 20 & 10 & 0 & 0 & 33.84644 \\
\hline 60 & 20 & 0 & 20 & 0 & 34.7954 \\
\hline 50 & 20 & 10 & 20 & 0 & 37.23108 \\
\hline 60 & 20 & 0 & 0 & 20 & 34.47908 \\
\hline 50 & 20 & 10 & 0 & 20 & 36.89262 \\
\hline 40 & 20 & 0 & 20 & 20 & 37.92699 \\
\hline 30 & 20 & 10 & 20 & 20 & 40.58188 \\
\hline
\end{tabular}
porosity and water absorption then the sugarcane waste then cullet then Homra.

Table 4. Wastes addition effect on open porosity 
Table 5. Wastes addition effect on cold water absorption

\begin{tabular}{|c|c|c|c|c|c|}
\hline \multicolumn{5}{|c|}{ Percentage } & \multirow{2}{*}{$\begin{array}{c}\text { Cold Water } \\
\text { Absorption, } \\
\text { A (\%) }\end{array}$} \\
\hline Desert Clay & $\mathrm{H}$ & $\mathrm{C}$ & W & S & \\
\hline 100 & 0 & 0 & 0 & 0 & 10.159 \\
\hline 90 & 0 & 10 & 0 & 0 & 11.0732773 \\
\hline 80 & 0 & 0 & 20 & 0 & 11.3780464 \\
\hline 70 & 0 & 10 & 20 & 0 & 12.40207058 \\
\hline 80 & 0 & 0 & 0 & 20 & 11.2764567 \\
\hline 70 & 0 & 10 & 0 & 20 & 12.2913378 \\
\hline 60 & 0 & 0 & 20 & 20 & 12.6296315 \\
\hline 50 & 0 & 10 & 20 & 20 & 13.76629834 \\
\hline 80 & 20 & 0 & 0 & 0 & 10.8700979 \\
\hline 70 & 20 & 10 & 0 & 0 & 11.84840671 \\
\hline 60 & 20 & 0 & 20 & 0 & 12.17450965 \\
\hline 50 & 20 & 10 & 20 & 0 & 13.27021552 \\
\hline 60 & 20 & 0 & 0 & 20 & 12.06580867 \\
\hline 50 & 20 & 10 & 0 & 20 & 13.15173145 \\
\hline 40 & 20 & 0 & 20 & 20 & 13.51370571 \\
\hline 30 & 20 & 10 & 20 & 20 & 14.72993922 \\
\hline
\end{tabular}

Table 6. Wastes addition effect on hot water absorption

\begin{tabular}{|c|c|c|c|c|c|}
\hline \multicolumn{5}{|c|}{ Percentage } & \multicolumn{1}{c|}{$\begin{array}{c}\text { Hot Water } \\
\text { Absorption, } \\
\text { A } \%)\end{array}$} \\
\hline Desert Clay & H & C & W & S & A \\
\hline 100 & 0 & 0 & 0 & 0 & 15.513 \\
\hline 90 & 0 & 10 & 0 & 0 & 17.21909367 \\
\hline 80 & 0 & 0 & 20 & 0 & 1768447458 \\
\hline 70 & 0 & 10 & 20 & 0 & 1962976678 \\
\hline 80 & 0 & 0 & 0 & 20 & 1752934761 \\
\hline 70 & 0 & 10 & 0 & 20 & 1945757585 \\
\hline 60 & 0 & 0 & 20 & 20 & 1998345628 \\
\hline 50 & 0 & 10 & 20 & 20 & 2218163647 \\
\hline 80 & 20 & 0 & 0 & 0 & 1690883973 \\
\hline 70 & 20 & 10 & 0 & 0 & 187688121 \\
\hline 60 & 20 & 0 & 20 & 0 & 1927607729 \\
\hline 50 & 20 & 10 & 20 & 0 & 2139644579 \\
\hline 60 & 20 & 0 & 0 & 20 & 1910698889 \\
\hline 50 & 20 & 10 & 0 & 20 & 2120875767 \\
\hline 40 & 20 & 0 & 20 & 20 & 2178196734 \\
\hline 30 & 20 & 10 & 20 & 20 & 2417798375 \\
\hline
\end{tabular}

\subsection{Wastes Addition Effect on Compressive Strength}

The compressive strength decreases by the increase in waste percentage as shown in the following table. When the porosity increases and then the strength decreases. Adding more wastes will result in porosity increasing as illustrated before in the porosity calculation section and thus compressive strength decreases. This is the most important property required by American standards and locally harmonized standards. Compressive strength value should exceed 17.2 MPa according to ES 4763 / 2006 and ASTM C 62 / 2013 [25, 26]. 
Table 7. Wastes addition effect on compressive strength

\begin{tabular}{|c|c|c|c|c|c|}
\hline \multicolumn{4}{|c|}{ Percentage } & \multicolumn{2}{c|}{$\begin{array}{c}\text { Breaking } \\
\text { Strength, } \\
\text { Desert Clay }\end{array}$} \\
\hline 100 & H & C & W & S & 0 \\
\hline 90 & 0 & 10 & 0 & 0 & 24.04849 \\
\hline 80 & 0 & 0 & 20 & 0 & 23.44977 \\
\hline 70 & 0 & 10 & 20 & 0 & 22.33046 \\
\hline 80 & 0 & 0 & 0 & 20 & 23.646 \\
\hline 70 & 0 & 10 & 0 & 20 & 20.12426 \\
\hline 60 & 0 & 0 & 20 & 20 & 19.62324 \\
\hline 50 & 0 & 10 & 20 & 20 & 16.70063 \\
\hline 80 & 20 & 0 & 0 & 0 & 24.46491 \\
\hline 70 & 20 & 10 & 0 & 0 & 20.8212 \\
\hline 60 & 20 & 0 & 20 & 0 & 20.30283 \\
\hline 50 & 20 & 10 & 20 & 0 & 19.33374 \\
\hline 60 & 20 & 0 & 0 & 20 & 20.47273 \\
\hline 50 & 20 & 10 & 0 & 20 & 17.4236 \\
\hline 40 & 20 & 0 & 20 & 20 & 16.98982 \\
\hline 30 & 20 & 10 & 20 & 20 & 16.98982 \\
\hline
\end{tabular}

The equation that shows breaking strength (BS) as function of all wastes percentages using data analysis option in Excel program is the following

$$
\begin{aligned}
& B S=26.28045-0.12128 H-0.13476 C- \\
& 0.21822 W-0.18164 S
\end{aligned}
$$

From the above equations it was found than the addition of wheat straw ash has the highest effect on compressive strength then the sugarcane waste then cullet then Homra.

\subsection{Waste Recycling Possibility of into Building Bricks Bodies}

According to the previous measured properties and after using design expert program it was found that the resulted optimum samples which has a breaking strength and MOR complied with the standard values (ES 4763 / 2006 and ASTM C 62 / 2013) $[25,26]$ as shown in the following table. The design expert program was used to determine the composition of the optimum sample and 5 samples were prepared using the obtained composition and their properties were determined to make sure and then the average values of their properties were obtained and compared with the standard properties values in ES 4763 / 2006 and ASTM C 62 / 2013 and the following table shows that optimum samples were complied with the standards values of building bricks.

\begin{tabular}{|c|c|c|}
\hline Property & Optimum & Standard \\
\hline \multirow{5}{*}{$\begin{array}{c}\text { Composition of } \\
\text { Optimum Clay } \\
\text { Bricks }\end{array}$} & $\begin{array}{c}38 \% \text { Desert } \\
\text { Clay }\end{array}$ & \\
\hline & $20 \%$ Homra & \\
\hline & $10 \%$ Cullet & \\
\hline & $\begin{array}{l}15 \% \text { Wheat } \\
\text { Straw Ash }\end{array}$ & \\
\hline & $\begin{array}{c}17 \% \\
\text { Sugarcane }\end{array}$ & \\
\hline $\begin{array}{c}\% \text { Cold Water } \\
\text { Absorption }\end{array}$ & 13.3214 & No limit \\
\hline $\begin{array}{c}\% \text { Boiling Water } \\
\text { Absorption }\end{array}$ & 20.0842 & $\begin{array}{c}\text { Maximum value } \\
\text { equals } 22 \%\end{array}$ \\
\hline $\begin{array}{l}\text { Compressive } \\
\text { Strength, MPa }\end{array}$ & 19.1243 & $\begin{array}{c}\text { Minimum } 17.2 \\
\mathrm{MPa}\end{array}$ \\
\hline
\end{tabular}

Table 8. Optimum Samples Properties

\section{Conclusion}

The agriculture wastes are considered as a big environmental problem. The main purpose of this research was to determine the possibility of producing fired clay bricks from a mixture of agriculture wastes in addition to other wastes. The first type of wastes is the cullet while the second type is the wastes is the waste clay bricks (Homra) and the third is an agricultural residue obtained from wheat and sugarcane cultivation.

Analysis of raw materials was done using XRF and sieve analysis. Cubic brick samples of approximate dimensions $50 \times 50 \times 50 \mathrm{~mm}^{3}$ were formed by $1 \mathrm{MPa}$ dry pressing then drying overnight 
at $120^{\circ} \mathrm{C}$. Tile samples were fired at temperatures in range off $850{ }^{\circ} \mathrm{C}$ for 15 min soaking time. Water absorption, apparent porosity, and mechanical properties were determined and compared to ES 4763 / 2006 and ASTM C 62 / 2013 standards.

According to the previous experimental work, it was found that the samples that has a composition (38\% Desert clay, 20\% Homra, 10\% cullet, 15\% Wheat ash straw, $17 \%$ sugarcane) has the optimum properties with respect to ES 4763 / 2006 and ASTM C 62 / 2013 standards.

\section{Acknowledgements}

The author would like to acknowledge the British University in Egypt (BUE) for funding this research through young investment research grand (YIRG) and also Ceramica Venus Company due to their support and providing facilities required to perform this work. The author would like to thank Prof. Magdi F. Abadir for everything. The author is proud to be his student.

\section{References:}

[1] Dlamini, M., 2014. Clay and Concrete brick. Retrieved from Research Space: https://researchspace.csir.co.za/dspace/bitstream /handle/10204/7575/Dlamini_2014.pdf?sequenc $\mathrm{e}=1$ \&isAllowed $=\mathrm{y}$

[2] Dondi M., Marsigli M., Fabbri B., "Recycling of industrial and urban wastes in brick production-A review", Tile \& Brick International, Vol 13, No. 3, 1997, pp. 18-225.

[3] Shakir A.A., Naganathan S., Mustafa K.N., "Properties of bricks made using fly ash, quarry dust and billet scale", Const. Build. Mater., Vol 41, 2013, pp 131-138.

[4] Vieira C. M. F., Sánchez R., Monteiro S. N., "Characteristics of clays and properties of building ceramics in the state of Rio de Janeiro", Brazil, Construction and Building Materials, Vol 22, No. 5, 2008, pp 781-787.

[5] Ugheoke, B. I., Onche, E. O., Amessan, O. N. and Asikpo, G. A., "Property and Optimization of Kaolin - Rice Husk Insulating Fire - Bricks", Leonardo Electronic Journal of Practices and Technologies, Vol 9, 2006, pp 167-178.

[6] Elwan M.M., Atriss M.S., Mahmoud A.A., Salem A.S., "Characterization of rice straw ash and its use in clay bricks", Proc. 1st Sci. Environ. Conf., Zagazig Univ. Egypt, 2006, pp 79-92.

[7] Demir I., Effect of organic residues addition on the technological properties of clay bricks", Waste management, Vol 28, 2008, pp 622-627,.
[8] Ajam L. Ouezdou M.B., Felfoul H.S., El Mensi R., "Characterization of the Tunisian phosphogypsum and its valorization in clay bricks", Const. Build. Mater., Vol 23, No. 10, 2009, pp 3240-3247.

[9] AbdulKadeer A., Mohajerani A., "Bricks: an excellent building material for recycling wastes", Proc. IASTED Int. Conf., EME, Calgary, Canada, July 2011, pp 108-115.

[10] Abdullatif K. G., Guirguis M., N., Moussa R. R., "properties of Fire Clay bricks after adding cigarette filters", WSEAS TRANSACTIONS on ENVIRONMENT and DEVELOPMENT, Vol 16, 2020, pp. 671-679.

[11] Kumar D. C., Vasanthi P., Devaraju A., "Experimental studies on composite bricks using black cotton soil, fly ash and granite waste" materials today, Vol 39, No. 1, 2021, pp 868-874

[12] Limami H., Manssouri I., Cherkaoui K., Khaldoun A., "Recycled wastewater treatment plant sludge as a construction material additive to ecological lightweight earth bricks" Cleaner Engineering and Technology, Vol 2, 2021.

[13] Aneke F. I., Shabangu C., "Green-efficient masonry bricks produced from scrap plastic waste and foundry sand" Case Studies in Construction Materials, Vol 14, 2021

[14] Chou M.I.M., Chen L.M., Chou F.S.J., "Spent Equilibrium Catalyst for Manufacturing Fired Bricks": A Commercial Production Demonstration, Int. J. environ. Sust., Vol 8, Issue 3, 2013, pp 19-35.

[15] Hassan, S.F., Nasr, M.I., "Sugar Industry in Egypt" Sugar Tech, Vol 10, No. 3, 2008, pp 204-209.

[16] Hamada, Y.M., "Water Resources Reallocation in Upper and Middle Egypt" EWRA European Water, EW Publications, Vol 33, 2011, pp 3344

[17] Economic and Social Commission for Western Asia (ESCWA). "Increasing the competitiveness of small and medium-sized enterprises through the use of environmentally sound technologies: assessing the potential for the development of second-generation biofuels in the ESCWA region" United Nations, New York, 2009.

[18] Xiao, B., Sun, X.F., Sun, R.C., "Chemical, structural and thermal characterization of alkali soluble lignins and hemicelluloses and cellulose from maize stems, rye straw and rice straw". Polymer Degradation and Stabilization, Vol 74, 2001, pp 307-319 
[19] Hassan A. M., Abadir M. F., Moselhy H.., 2018 "Use of Agricultural Waste in the Preparation of Insulating Fireclay Bricks". International Journal of Applied Engineering Research, Vol 13, 2018, pp. 10819-10825.

[20] Dawoud N., Micheal A., Moussa R. R., "A Review on Investigating the experimental process for partial replacement of cement with sugarcane bagasse in the construction industry". 13th International Conference on Civil and Architecture Engineering (ICCAE-13), IOP Conf. Series: Materials Science and Engineering 974, pp. 1-27.

[21] ASTM D422-63(2007)e2, Standard Test Method for Particle-Size Analysis of Soils (Withdrawn 2016), ASTM International, West Conshohocken, PA, 2007, www.astm.org.

[22] ASTM C67-13, Standard Test Methods for Sampling and Testing Brick and Structural Clay Tile, ASTM International, West Conshohocken, PA, 2013, www.astm.org

[23] ASTM C 373/1988 (Reapproved 2006), "Standard test method for water absorption, bulk density, apparent porosity and apparent specific gravity of fired white ware products", Annual book of American Society for Testing of Material (ASTM), US, 15 (2), (April 2012).

[24] BS EN ISO 10545 - 4/2012, "Ceramic tiles Part 4: Determination of modulus of rup-ture and breaking strength", the British Standards Institution (BSI), London, (2012)

[25] ES 4763 / 2006, "Testing of modulus of rupture for dense shaped refractory products", Egyptian Organization for Standardization and Quality, Cairo, Egypt, (2006).

[26] ASTM C62-13a, Standard Specification for Building Brick (Solid Masonry Units Made From Clay or Shale), ASTM International, West Conshohocken, PA, 2013, www.astm.org
Creative Commons Attribution License 4.0 (Attribution 4.0 International, CC BY 4.0)

This article is published under the terms of the Creative Commons Attribution License 4.0 https://creativecommons.org/licenses/by/4.0/deed.en US 